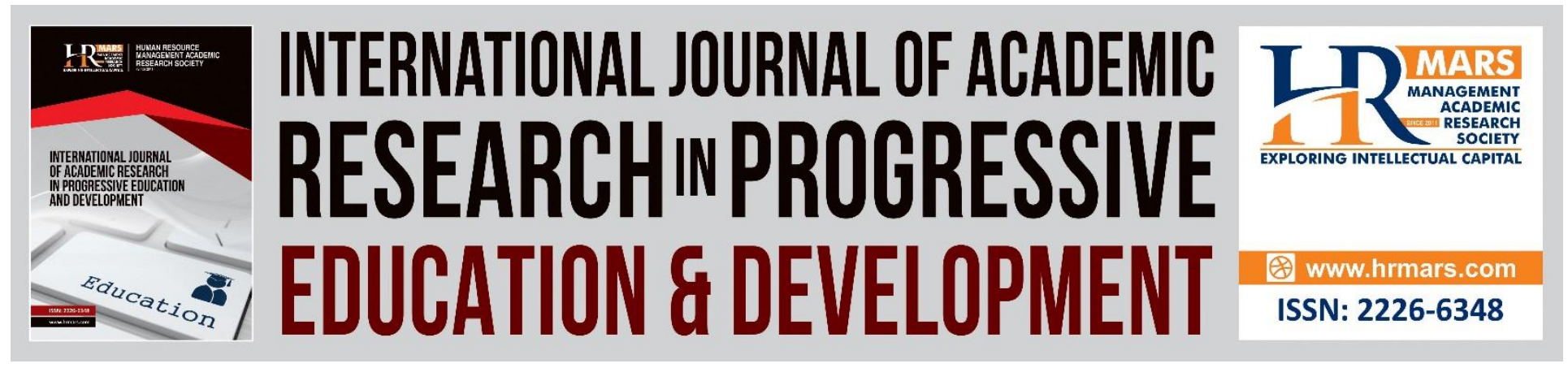

\title{
Sleep Quality Among University Students During Covid-19 Lockdown
}

Nur Aliana Md Zuki, Mohd Azim Nural Azhan, Harris Kamal Kamaruddin, Ahmad Fikri Mohd Kassim, Mohamad Firdaus Ahmad, Al Hafiz Abu Bakar

To Link this Article: http://dx.doi.org/10.6007/IJARPED/v10-i2/10151

DOI:10.6007/IJARPED/v10-i2/10151

Received: 07 April 2021, Revised: 29 April 2021, Accepted: 18 May 2021

Published Online: 23 June 2021

In-Text Citation: (Zuki et al., 2021)

To Cite this Article: Zuki, N. A. M., Azhan, M. A. N., Kamaruddin, H. K., Kassim, A. F. M., Ahmad, M. F., \& Bakar, A. H. A. (2021). Sleep Quality Among University Students During Covid-19 Lockdown. International Journal of Academic Research in Progressive Education and Development, 10(2), 814-822.

Copyright: (C) 2021 The Author(s)

Published by Human Resource Management Academic Research Society (www.hrmars.com)

This article is published under the Creative Commons Attribution (CC BY 4.0) license. Anyone may reproduce, distribute, translate and create derivative works of this article (for both commercial and non-commercial purposes), subject to full attribution to the original publication and authors. The full terms of this license may be seen at: http://creativecommons.org/licences/by/4.0/legalcode

Vol. 10(2) 2021, Pg. 814 - 822

http://hrmars.com/index.php/pages/detail/IJARPED

JOURNAL HOMEPAGE

Full Terms \& Conditions of access and use can be found at http://hrmars.com/index.php/pages/detail/publication-ethics 


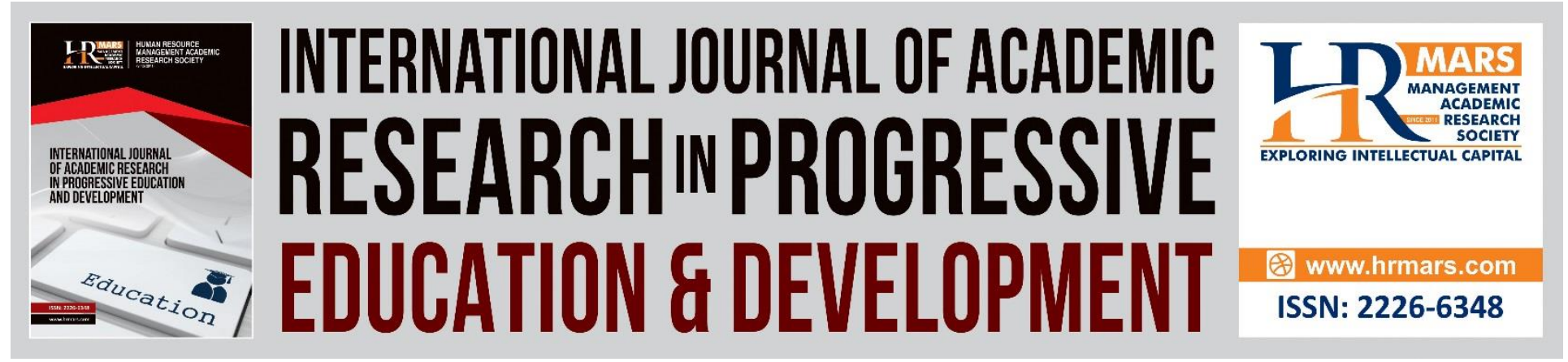

\title{
Sleep Quality Among University Students During Covid-19 Lockdown
}

\section{Nur Aliana Md Zuki ${ }^{1}$, Mohd Azim Nural Azhan ${ }^{1}$, Harris Kamal Kamaruddin ${ }^{1}$, Ahmad Fikri Mohd Kassim ${ }^{1}$, Mohamad Firdaus Ahmad $^{2}$, Al Hafiz Abu Bakar ${ }^{1}$}

${ }^{1}$ Faculty of Sports Science and Recreation, Universiti Teknologi MARA, Cawangan Perlis, Kampus Arau, 02600, Arau, Perlis, ${ }^{2}$ Faculty of Sports Science and Recreation, Universiti Teknologi MARA, Cawangan Negeri Sembilan, Kampus Seremban, 70300, Seremban, Negeri Sembilan Email: aliyanazuki@gmail, azimazhan@uitm.edu.my, harris540@uitm.edu.my, ahmadfikri@uitm.edu.my, firdaus466@uitm.edu.my, alhafizab@uitm.edu.my

\begin{abstract}
Good quality of sleep is an acknowledged source of physical and mental wellbeing, happiness, and vitality. Without enough hours of restorative sleep, the individual will not be able to function, study, develop and interact even near to their true potential at a point of time. University student's lifestyle changes with the new life of studying. Sleep problems and sleep disorders severely impair university students' academic success. To date, there is limited study on the level of sleep quality among university students during the covid-19 lockdown. The purpose of this study was to determine the level of sleep quality among university students between faculty during the Covid-19 lockdown. A total of 417 respondents among Universiti Teknologi MARA (UiTM) Perlis were set up to answer the questionnaire by Pittsburgh Sleep Quality Index (PSQI). Based on the data, there was a significant difference in the level of sleep quality among UiTM Perlis Student $(p=0.001)$. The mean global score for all students was $(6.47 \pm 3.105)$. Faculty of Architecture Planning and Surveying had a higher mean global score ( $8.95 \pm 2.882)$. Faculty of Sports Science and Recreation had a lower mean global score $(3.86 \pm 2.014)$. From the result, Faculty Architecture Planning and Surveying have poor sleep quality while Faculty of Sports Science and Recreation have good sleep quality. In conclusion, the study showed the level of sleep quality among UiTM Perlis students is slightly greater on poor sleep. This might be due to poor sleep habits like having an irregular sleep pattern and psychological issues such as stress.
\end{abstract}

Keywords: Covid-19, Sleep Quality Index, University Students

\section{Introduction}

Sleep has critical role in physiology and cognitive human functioning and also physical recovery (Mah et al., 2018). The brain remains active when sleeping, performing biological 
maintenance that keeps the body working in peak shape and training the human for the day ahead. Without enough hours of restorative sleep, the individual will not be able to function, study, develop and interact even near to their true potential at a point of time (Smith, Robinson \& Segal, 2019). However, sleep patterns and habits of an individual are different depending on their age, occupational demands, social engagements, somatic conditions and also individual physiological characteristics (Augner, 2011; Lemma et al., 2012).

It is important to achieve more insight in what determines perceived sleep quality as it can be indicative of sleep problems as well as other health consequences (Goelema, 2018).The university student's lifestyle changes with the new life of studying. This change may influence the quality of sleep (Çelik et al., 2018). Sleep problems and sleep disorders severely impair university students' academic success. Sleep problems in university students are often connected with mental health issues (Schlarb \& Friedrich, 2017). Groups of leading sleep scientists have reached a consensus about the average sleep duration which is a young adult needs an average of about 7-8 hours of sleep per night (Watson et al., 2015). Student life is chaotic, and the majority of students do not get enough sleep to perform well in class and on assignments An increasing body of research, on the one hand, has reported that technology leads to sleep deficits (Rodgers et al., 2016). Students tend to use devices and gadgets late at night which may impair their sleeping pattern. Blue light from devices and gadgets can suppress the secretion of melatonin thus reducing the sleep quality (Levenson et al., 2016; Orzech et al., 2016).

One of the risky groups, founded in the literature, for being concerned by disorders of sleep are students (Augner, 2011; Lemma et al., 2012; Quick et al., 2016). Most of students these days taking easy about the importance of sleep quality in their daily life. They may not aware that having a good sleep quality may improve their productivity level. Most of previous study was looking on the level sleep quality among elderly and athlete. To date, there is limited study on the level of sleep quality among university students during the Covid-19 lockdown. The purpose of this study was to determine the level of sleep quality among UiTM Perlis students between faculty during the Covid-19 lockdown.

\section{Methodology \\ Respondents and Procedures}

The survey was completed by 417 UiTM Perlis students. 54 students from Faculty of Accounting, 59 students from Faculty of Agrotechnology and Plantation, 59 students from Faculty of Applied Science, 56 students of Faculty Architecture Planning and Surveying, 64 students of Faculty of Business Management, 59 students from Faculty of Computer Science and Mathematics, and 66 students from Faculty of Sports Science. The survey was conducted by using an online platform, accessible through any device with internet connection. The process of data collection used in this survey was by using Google form. The link for the form was disseminated through institutional group and private social network via WhatsApp application. It was totally efficient for the research objectives because it facilitated the wide distribution of the survey questionnaire during a period where, due to the pandemic, there are many territorial constraints. There will be no request to identify the respondent's information. The complete confidentiality 
of the responses is assured. The completion of the questionnaire takes estimates of 10 to 15 minutes.

\section{Instrumentations}

The main component of the questionnaire consist of two section which section A were question on demographic survey of the respondents and the section B were question consists of 10 self-rated questions was about their sleep quality (Buysse et al., 1989). The concerns were regarding the respondent's normal sleep patterns during the past month. The Pittsburgh Sleep Quality Index (PSQI) is a self-reported sleep quality measure and sleep disturbance indicator. PSQI consists of 19 self-ranked questions and five questions scored by a roommate or bed companion. The 19 self-rated questions measure a broad variety of sleep quality indicators include assessments of sleep length and latency, as well as the occurrence and extent of common sleep related problems. These 19 questions were gathered into seven component scores, each weighted similarly on a 0-3 scale. The seven component scores were at that point summed to abdicate a worldwide PSQI score, which includes a run of 0-2 higher scores demonstrate more awful sleep quality (Buysse et al., 1989). All the data was analyzed by using Statistical Package for the Social Sciences (IBM SPSS Statistics) version 25.0. Thus, hypothesis was tested used One-way Analysis of Variance (ANOVA) with significant value of $<0.05$.

\section{Results}

The survey was completed by 417 students. The rates of good sleeper and poor sleeper based on global PSQI score. Poor sleep quality, which was indicated by a global PSQI score $>5$, was reported by 239 (57.3\%) students. Table 1 shows the demographic data of the study. $41.7 \%$ of the participants was male and $58.3 \%$ are female. Comparison between age shows that $48.7 \%$ of the participants are age between $18-20$ years, $49.2 \%$ are age between $21-24$ years and only $2.2 \%$ are above 25 years old. For the number of participants for each faculty, $14.1 \%$ participants from Faculty of Plantation and Agrotechnology, Faculty of Applied Science and Faculty of Computer Science and Mathematics respectively, 15.8\% are from Faculty of Sports Science and Recreation, 15.3\% are from Faculty of Business Management, 13.4\% are from Faculty of Architecture Planning and Surveying and $12.9 \%$ of participants are from Faculty of Accounting. 
INTERNATIONAL JOURNAL OF ACADEMIC RESEARCH IN PROGRESSIVE EDUCATION AND DEVELOPMENT

Vol. 10, No. 2, 2021, E-ISSN: 2226-6348 @ 2021 HRMARS

Descriptive result

Table 1 Descriptive Data

\begin{tabular}{lc}
\hline & Percentage (\%) \\
\hline Gender & 41.7 \\
Male & 58.3 \\
Female & \\
\hline Age & \\
$18-20$ years old & 48.7 \\
$21-24$ years old & 49.2 \\
Above 25 years old & 2.2 \\
& \\
\hline Faculty & \\
Faculty of Plantation and Agrotechnology & 14.1 \\
Faculty of Applied Science & 14.1 \\
Faculty of Sports Science and Recreation & 15.8 \\
Faculty of Computer Science and Mathematics & 14.1 \\
Faculty of Business Management & 15.3 \\
Faculty of Architecture Planning and Surveying & 13.4 \\
Faculty of Accounting & 12.9 \\
\end{tabular}

Table 2 Mean and Standard Deviation for Global Score of UiTM Perlis Students

Mean

Std. Deviation

\begin{tabular}{llll} 
& Faculty of Accounting & 6.80 & 2.506 \\
& Faculty of Agrotech and Plantation & 6.81 & 2.719 \\
Global PSQI & Faculty of Applied Science & 6.17 & 2.679 \\
& Faculty of Architecture Planning and Surveying & 8.95 & 2.882 \\
& Faculty of Business Management & 6.22 & 2.968 \\
& Faculty of Computer Science and Mathematics & 7.00 & 3.538 \\
& Faculty of Sports Science and Recreation & 3.86 & 2.014 \\
\hline & & & \\
\hline
\end{tabular}

The mean global score for all students was $6.47 \pm 3.12$. Faculty of Architecture Planning and Surveying had a higher mean global score (8.95 \pm 2.88$)$ and Faculty of Sports Science and Recreation had a lower mean global score $(3.86 \pm 2.01)$. 
INTERNATIONAL JOURNAL OF ACADEMIC RESEARCH IN PROGRESSIVE EDUCATION AND DEVELOPMENT

Vol. 10, No. 2, 2021, E-ISSN: 2226-6348 @ 2021 HRMARS

Table 3 One-Way Analysis of Variance (ANOVA) for the differences on level of sleep quality

\begin{tabular}{lccccc}
\hline \multicolumn{6}{c}{ ANOVA } \\
\hline \multicolumn{7}{c}{ Global PSQI } \\
\hline Sum of Squares & df & Mean Square & F & Sig. \\
\hline Within Groups & 830.423 & 6 & 138.404 & 17.847 & 0.001 \\
\hline Total & 3179.563 & 410 & 7.755 & & \\
\hline
\end{tabular}

There was a significant effect of sleep quality at the $p<0.05$ level between faculty. Post hoc comparisons using the Tukey HSD test indicated that the mean score for Faculty of Sport Science and Recreation ( $M=3.86, S D=2.014)$ was significantly different with all the other faculties. Faculty of Architecture Planning and Surveying $(M=8.95, S D=2.88)$ had the highest score which indicates poor sleep quality compared to Faculty of Sport Sciences and Recreation which has the lowest score which indicates better sleep quality.

\section{Discussions}

The findings for the sleep quality among UiTM Perlis students were initially analyzed and have been summarized to the result of significance that has been obtained. Faculty Architecture Planning and Surveying have poor sleep quality might be due to psychological problems such as stress with their work project because due to the fieldwork compared to online coursework before MCO. Since MCO occur, they need to do more online coursework to replace their fieldwork. This finding was supported by previous research Guastella \& Moulds (2007) stated that more rumination of stressful life activity, such as test or task, was recorded by students with worse sleep. Other studies have shown that fatigue, depressive mood, and stress control problems are linked with inadequate sleep and poor quality of sleep (Wolfson, 2010).

According to the data, the Faculty of Sports Science and Recreation have good sleep quality probably because of they are still doing virtual exercise activity to fulfil their syllabus requirement which leads to having a good rest. This finding was supported by Mahfouz et al., (2020) which stated that students from universities who frequently exercised showed greater quality of sleep than those who exercised less. Moreover, research done by Badicu (2018) stated that physical exercise, if performed on a daily basis is helpful for the body and may improve the quality of sleep. According to Lastella et al (2014) cognitive functions, metabolic activity, immune function, and appetite control were included in physical conditions, while psychological conditions were mood disturbance, decision-making, and concentration. This condition is interrelated and becomes a process since sleep quality can be increased by physical activity and good sleep quality can boosts performance (Gerber et al., 2010).

The overall result of this study indicates that the UiTM Perlis students' level of sleep was slightly greater in the poor sleep category during Covid-19 lockdown. UiTM Perlis students tend to have poor sleep might be due to poor sleep habits like having an irregular sleep pattern. According to Hershner \& Chervin (2014), students get insufficient sleep when they wake up early and go to bed late and this will lead to students' circadian physiology. Moreover, poor sleep also 
leads to judgement impairment, irritability, agitation and inability to digest information in the short term, and for long term, it can contribute to cardiometabolic disorders and even increased mortality (Yazdi et al., 2016).

Based on the objective and purpose of the analysis which was to identify the level of sleep quality among UiTM Perlis students. There are significant differences in the sleep quality between faculties. The result suggested that the participant who lack of sleep quality probably do not have effective sleep management. Lack of sleep have been led to mental health problems such as impairments in learning, attention, decision-making and complex, divergent or creative thinking (Alhola \& Kantola, 2007; Curcio et al., 2006).

\section{Conclusion}

As conclusion, this study revealed a poor sleep quality among UiTM Perlis university students. Specifically, students from Faculty of Architecture Planning and Surveying demonstrated higher poor sleep quality compared to other students. In the long run poor sleep quality may pose several health problem and poor work productivity levels. Based on these findings, UiTM Perlis university students urgently need to be educated about the importance to sleep right and the negative aftereffects of poor sleep quality. A recommendation for the administration of university in UiTM Perlis is to establish health awareness and counselling that focus on improving students' study skill and their ability to adapt to their stressful study environment. For future research, it was recommended to look on the effect of sleep quality before, during and after Covid-19 lock down to compare the effect of Covid-19 lockdown towards the sleep quality of students.

\section{References}

Alhola, P., \& Polo-Kantola, P. (2007). Sleep deprivation: Impact on cognitive performance. Neuropsychiatric Disease and Treatment, 3(5), 553-567.

Badicu, G. (2018). Physical activity and sleep quality in students of the Faculty of Physical Education and Sport of Braşov, Romania. Sustainability (Switzerland), 10(7). https://doi.org/10.3390/su10072410

Buysse, D. J., Reynolds, C. F., Monk, T. H., Berman, S. R., \& Kupfer, D. J. (1989). The Pittsburgh Sleep Quality Index : A New Instrument Psychiatric Practice and Research.

Çelik, N., Ceylan, B., Ünsal, A., \& Çağan, Ö. (2018). Depression in health college students : relationship factors and sleep quality. Psychology, Health \& Medicine, 00(00), 1-6. https://doi.org/10.1080/13548506.2018.1546881

Curcio, G., Ferrara, M., \& De Gennaro, L. (2006). Sleep loss, learning capacity and academic performance. Sleep Medicine Reviews, 10(5), 323-337. https://doi.org/10.1016/j.smrv.2005.11.001

Gerber, M., Brand, S., Holsboer-Trachsler, E., \& Pühse, U. (2010). Fitness and exercise as correlates of sleep complaints: Is it all in our minds? Medicine and Science in Sports and Exercise, 42(5), 893-901. https://doi.org/10.1249/MSS.0b013e3181c0ea8c

Goelema, M. S. (2018). Perceived sleep quality in a personal health monitoring context Perceived sleep quality in a personal health monitoring context (Issue 2018). 
INTERNATIONAL JOURNAL OF ACADEMIC RESEARCH IN PROGRESSIVE EDUCATION AND

DEVELOPMENT

Vol. 10, No. 2, 2021, E-ISSN: 2226-6348 @ 2021 HRMARS

Guastella, A. J., \& Moulds, M. L. (2007). The impact of rumination on sleep quality following a stressful life event. Personality and Individual Differences, 42(6), 1151-1162.

https://doi.org/10.1016/j.paid.2006.04.028

Hershner, S. D., \& Chervin, R. D. (2014). Causes and consequences of sleepiness among college students. Nature and Science of Sleep, 6, 73-84. https://doi.org/10.2147/NSS.S62907

Lastella, M., Lovell, G. P., \& Sargent, C. (2014). Athletes' precompetitive sleep behaviour and its relationship with subsequent precompetitive mood and performance. European Journal of Sport Science, 14(SUPPL.1), 37-41. https://doi.org/10.1080/17461391.2012.660505

Levenson, J. C., Shensa, A., Sidani, J. E., Colditz, J. B., \& Primack, B. A. (2016). The association between social media use and sleep disturbance among young adults. Preventive Medicine, 85, 36-41. https://doi.org/10.1016/j.ypmed.2016.01.001

Mah, C. D., Kezirian, E. J., Marcello, B. M., \& Dement, W. C. (2018). Poor sleep quality and insufficient sleep of a collegiate student-athlete population. Sleep Health, 4(3), 251-257. https://doi.org/10.1016/j.sleh.2018.02.005

Mahfouz, M. S., Ali, S. A., Bahari, A. Y., Ajeebi, R. E., Sabei, H. J., Somaily, S. Y., Madkhali, Y. A., Hrooby, R. H., \& Shook, R. N. (2020). Association between sleep quality and physical activity in Saudi Arabian University students. Nature and Science of Sleep, 12, 775-782. https://doi.org/10.2147/NSS.S267996

Smith, M. A., Robinson, L., and Segal, R. M. (2019). Sleep Needs How many hours of sleep do you need? What happens when you don' $t$ get enough ? Explore the stages of sleep and how to get on a healthy sleep schedule. Why is sleep so important ? 1-7.

Orzech, K. M., Grandner, M. A., Roane, B. M., \& Carskadon, M. A. (2016). Digital media use in the $2 \mathrm{~h}$ before bedtime is associated with sleep variables in university students. Computers in Human Behavior, 55, 43-50. https://doi.org/10.1016/j.chb.2015.08.049

Rodgers, S., Maloney, B., Ploderer, B., \& Brereton, M. (2016). Managing stress, sleep and technologies: An exploratory study of Australian University students. Proceedings of the 28th Australian Computer-Human Interaction Conference, OzCHI 2016, 526-530. https://doi.org/10.1145/3010915.3010961

Schlarb, A. A., \& Friedrich, A. (2017). Sleep problems in university students - an intervention. 1989-2001.

Watson, N. F., Badr, M. S., Belenky, G., Bliwise, D. L., Buxton, O. M., Buysse, D., Dinges, D. F., Gangwisch, J., Grandner, M. A., Kushida, C., Malhotra, R. K., Martin, J. L., Patel, S. R., Quan, S. F., Tasali, E., Twery, M., Croft, J. B., Maher, E., Barrett, J. A., ... Heald, J. L. (2015). Joint Consensus Statement of the American Academy of Sleep Medicine and Sleep Research Society on the Recommended Amount of Sleep for a Healthy Adult: Methodology and Discussion. Journal of Clinical Sleep Medicine, 11(8), 931-952. https://doi.org/10.5664/jcsm.4950

Wolfson, A. R. (2010). Adolescents and Emerging Adults' Sleep Patterns: New Developments. Journal of Adolescent Health, 46(2), 97-99. https://doi.org/10.1016/j.jadohealth.2009.11.210

Augner, C. (2011). Associations of subjective sleep quality with depression score, anxiety, physical symptoms and sleep onset latency in students. Cent Eur J Public Health, 19(2), 115-117. doi:10.21101/cejph.a3647 
Lemma, S., Gelaye, B., Berhane, Y., Worku, A., \& Williams, M. A. (2012). Sleep quality and its psychological correlates among university students in Ethiopia: a cross-sectional study. BMC Psychiatry, 12, 237. doi:10.1186/1471-244x-12-237

Quick, V., Byrd-Bredbenner, C., Shoff, S., White, A. A., Lohse, B., Horacek, T., ... Greene, G. (2016). Relationships of Sleep Duration With Weight-Related Behaviors of U.S. College Students. Behav Sleep Med, 14(5), 565-580. doi:10.1080/15402002.2015.1065411

Yazdi, Z., Loukzadeh, Z., Moghaddam, P., \& Jalilolghadr, S. (2016). Sleep Hygiene Practices and Their Relation to Sleep Quality in Medical Students of Qazvin University of Medical Sciences. J Caring Sci, 5(2), 153-160. doi:10.15171/jcs.2016.016 